\title{
The Traditional Party and State Leadership System
}

\author{
Zengke $\mathrm{He}^{1}$
}

Received: 19 August 2015/Accepted: 9 December 2015/Published online: 3 March 2016

(C) Fudan University and Springer Science+Business Media Singapore 2016

\begin{abstract}
The traditional Party and state leadership system refers to the highly centralized Party and state leadership system which was created after the founding of the People's Republic of China in 1949 and was eventually established after the completion of the socialist transformation of private ownership of the means of production and the collectivization of the agricultural sector, as well as the establishment of a highly centralized planned economic system in the mid-1950s. The traditional Party and state leadership system is the source and foundation of the current Party and state leadership system. Though the centralized leadership with party control all enjoys some advantages, this kind of leadership system weakened the state and society, made party organizations bureaucratic and party cadres a special group with privileges. Mao Zedong tried to use the logic and method of revolution to improve this kind of leadership system but failed. This shows that the logic of revolution was unable to solve the drawbacks of traditional party and state leadership system under the ruling condition.
\end{abstract}

Keywords Traditional Party and state leadership system - Leadership principle · Leadership style

\section{Introduction}

The traditional Party and state leadership system refers to the highly centralized Party and state leadership system which was created after the founding of the People's Republic of China in 1949 and was eventually established after the completion of the socialist transformation of private ownership of the means of production and the collectivization of the agricultural sector, as well as the

Zengke He

hezengke65@163.com

1 Research Center for Chinese Politics, Peking University, Beijing, China 
establishment of a highly centralized planned economic system in the mid-1950s. This leadership system has formed its own leadership principle, and unique leadership style with institutional pillars, distinct advantages, as well as disadvantages that are difficult to overcome.

\section{The Basic Contents of the Traditional Party and State Leadership System}

The traditional Party and state leadership system has formed its specific leadership principle and unique leadership style, which jointly constitute its basic contents and main features.

\subsection{The Specific Leadership Principle of the Traditional Party and State Leadership System: "Centralized Leadership" Under the Control of the Party}

In the process of leading Chinese people in revolutionary struggles for state power, the Communist Party of China (CPC) created its own army, set up a regime on its revolutionary base, and mobilized the masses to set up various people's groups and mass organizations. This revolutionary mode of "building an army by the Party" and "establishing regime by the Party" decided on adherence to the Party's leadership to be the only way to the success of revolution and a fundamental principle of the Party and government leadership system. Adhering to the Party's leadership and how the Party leads are two different issues. The former is the fundamental principle or basic principle of the Party and government leadership system, while the latter is a specific leadership principle in the Party and government leadership system. With regard to upholding the Party's leadership and the administrative function of government bodies, the Party leaders have been resolutely against the Kuomintang's approaches like "one-party dictatorship" and "placing Party power above everything else". They advocate leading by the right lines, principles and policies of the Party and the vanguard and exemplary role of Party members and making sure that the government bodies at all levels have fulfilled their functions independently at the same time. The specific "centralized leadership" principle that the Party controls everything was gradually determined in the democratic revolution period. In 1942, the CPC Central Committee proposed the Party's centralized leadership principle against the uncoordinated work between the Party, government, army and people on the anti-Japanese base areas, which emphasized that the CPC Central Bureau and local Party committees were the supreme authorities of the Party, government and army on the anti-Japanese base areas. The military and political committees, governments, and Party societies (later called Party leading groups) of civil organizations should unconditionally implement the resolutions, decisions, and instructions from them (Song and Gang 1987). After the establishment of the People's Republic of China, the Party's centralized leadership principle further rose from the leadership principle of Party and government leadership system within the range of revolutionary bases to the 
nationwide leadership principle of the Party and state leadership system. In the mid1950s, after the completion of the socialist transformation of private ownership of the means of production and the establishment of a highly centralized planned economic system, the Party's centralized leadership principle further developed as the leadership principle that "the Party leads all", "the Party controls all", and "the Party secretary takes command". As the Party's supreme leader, Comrade Mao Zedong repeatedly stressed that "with regard to industry, agriculture, commerce, education, military, government, and the Party, the Party should lead all seven aspects", and that "with regards to the party, government, military, people, and education, the Party should lead them all". ${ }^{1}$ He also stressed that all work shall be "under the command of the Party secretary". In this way, as Comrade Deng Xiaoping profoundly noted, "Over-concentration of power means inappropriate and indiscriminate concentration of all power in Party committees in the name of strengthening centralized Party leadership. Moreover, the power of the Party committees themselves is often in the hands of a few secretaries, especially the first secretaries, who direct and decide everything. Thus, centralized Party leadership often turns into leadership by individuals" (Xiaoping 1994). The centralized leadership system that the Party controls all is not only the ideological basis of the Party and state leadership system but also the fundamental feature of this leadership system.

\subsection{State Power's Internal Leadership System and Party's Leadership System to State Power: Virtual and Practical}

In accordance with the provisions of the 1954 Constitution, the organizational principle of state authorities is democratic centralism. The National People's Congress is the supreme state authority and the presidium elected during the meeting presides over the meeting. When the Congress is in recess, the standing committee presides over the daily work and exercises the corresponding powers and it is also accountable to and reports work to the National People's Congress. As the supreme state administrative body, the State Council is the executive body of the state supreme power body. The State Council, together with the Supreme People's Court and the Supreme People's Procuratorate are all accountable to and report work to the National People's Congress and its standing committee. In accordance with the provisions of the constitution, the State Council and its functional departments adopt the chief executive responsibility system where the premier leads the work of the State Council and ministers are responsible for the management of different ministries. As for central-local relationship, the National People's Congress does not lead local people's congresses; local people's governments obey the centralized leadership of the Central People's Government; the Supreme Court supervises local courts rather than leads them while local people's

\footnotetext{
1 This is Mao Zedong's speech regarding the issue that Deng Xiaoping joined the Politburo and served as chief of the general staff during his interview with the members of the Politburo in December 1973. Mao Zedong had expressed many similar statements in other places, such as "With regard to industry, agriculture, commerce, education, military, government, and the Party, the Party should lead all the seven aspects." See Zedong (1986).
} 
procuratorates adopt a dual leadership system, which is, a local people's procuratorate is accountable to its local people's congress and obeys the centralized leadership of the Supreme People's Procuratorate at the same time. The personnel appointment and removal of main leaders of the local government, court and procuratorate is determined by its corresponding local people's congresses on the basis of a list of candidates nominated by the local Party committee.

In contrast, the Party's Leadership System to State Power is more complex, sophisticated and powerful. In accordance with the provisions of the 1956 Party Constitution, the CPC Central Committee exerts leadership over the work of the various central state organs through the Party leading groups (the Party's core leadership team in the leading institutions is referred to as the party leading group, the same below) of the National People's Congress, the State Council, the Supreme Court, the Supreme People's Procuratorate, and other central state organs. The Party's Central Committee leads the party committees at all levels and the party leading groups of state organs. The Party's leadership toward the state organs is achieved by the system of putting cadres under the Party's supervision, examination, and approval of requests for instructions and reports from the Party leading groups of state organs, examination and approval of the Party's internal cases that the judicial authority handled, release of resolutions and instructions, and inspection of their implementation. Though the Party's grass-roots organizations set up in state organs, i.e. the Party committees or the general Party branches, Party branches, etc., cannot lead and supervise the work of state organs, they have responsibility to supervise the ideological and political work of all Party members in the organs and can report shortcomings in the work to the higher party authority.

The focus of the Party's leadership over state authorities is the leadership of the government. According to the provisions of the document modified by Comrade Mao Zedong in person, "the leadership responsibility of the CPC Central Committee and Party committees at all levels for the government, financial and economic work, and industrial construction is: (1) all major and important guidelines, policies, and plans must be worked out by the CPC Central Committee in a unified manner, which makes the Party's resolutions, gives instructions, and examines and approves the recommendations from the leaders of state organs and the Party groups; all representative central organs and Party committees at all levels should firmly ensure the implementation of all resolutions, directives and decrees by the CPC Central Committee and the Central People's Government, develop their own resolutions or instructions which are not in conflict with the resolutions, directives and decrees by the CPC Central Committee, and ensure the completion of the tasks given by the Central Committee and higher authorities. (2) Examine the implementation of the Party's resolutions and directives" (Zedong 1999). According to Comrade Mao Zedong's instructions, major policies and specific arrangements are handled by the Party committees at all levels. The main task of Party leading groups is to ensure the effective implementation of the Party's resolutions and directives on governmental work. The Party leading groups have the right to make recommendations, but the final decision is in the hands of the party committees. Except for achieving leadership over power organs through the Party group system and the grassroots Party organizations in the organs, the Party 
committees at all levels also strengthened their leadership over the government by introducing special leadership on different sectors, setting-up counterparts of government departments, etc. Special leadership on different sectors refers to dividing government work into several sectors according to their features, such as finance and trade, public transportation, agriculture, culture and education, politics and law and so on, and then setting up corresponding leading groups, and the standing committee members (later changed into the secretaries) of the same level of said Party committee exerting split leadership over the work. After the founding of the People's Republic of China, the Party learnt the practice of the former Soviet Union to set counterparts of government departments in the Party committees. The counterparts mainly managed the cadres of the corresponding government departments in the early 1950s, while they both managed the cadres and business of the corresponding government departments in the late $1950 \mathrm{~s}^{2}$ The Party leading groups of the government and those of its departments were the core leadership of the government and its functional departments. The Party leading groups had the right to make recommendations for internal cadres and their work (while the final decision rested with the Party committee, its direct leaders, and the corresponding administrative departments). The leaders who were not party members were excluded from the core leadership and could not participate in core decisionmaking. As for the central-local relationship, compared with the leadership between two levels of governments, the CPC Central Committee exerted more powerful leadership over local Party committees and held the right of appointment, removal, and taking disciplinary actions against the personnel of local party committees and governments.

The Party's comprehensive and strong leadership over state power weakens the statutory leadership within the state regime. The Party leading groups of the government, court, and procuratorate are accountable to and report work to the Party committees of the same level, who hold the power of appointment and removal of their personnel, approval of their business work, and taking disciplinary actions. This kind of leadership is practical and strong and the government, court and procuratorate are indeed the executive organs of the Party committee. In contrast, the statutory leadership that the government, court and procuratorate are accountable to and report work to the people's congress and its standing committee is weak and virtual. The Party group system, the system of special leadership on different sectors, and leadership model of establishing counterparts of government departments that the Party committee implemented have greatly weakened the statutory leadership of chief executive responsibility system and other leadership systems of the government and its functional departments. The chief executives do not have the rights of personnel appointment and making decision in government, and therefore the leadership chief executive responsibility system is difficult to implement. The functions and rights of leaders of the Party committee and the deputy leaders of the government, and those of Party committee departments and government functional

\footnotetext{
${ }^{2}$ Pang Song and Han Gang have quite detailed discussions of the Party committees' special leadership on different sectors and the establishment of corresponding departments in the party committees. For further information, readers can refer to Song and Gang (1987).
} 


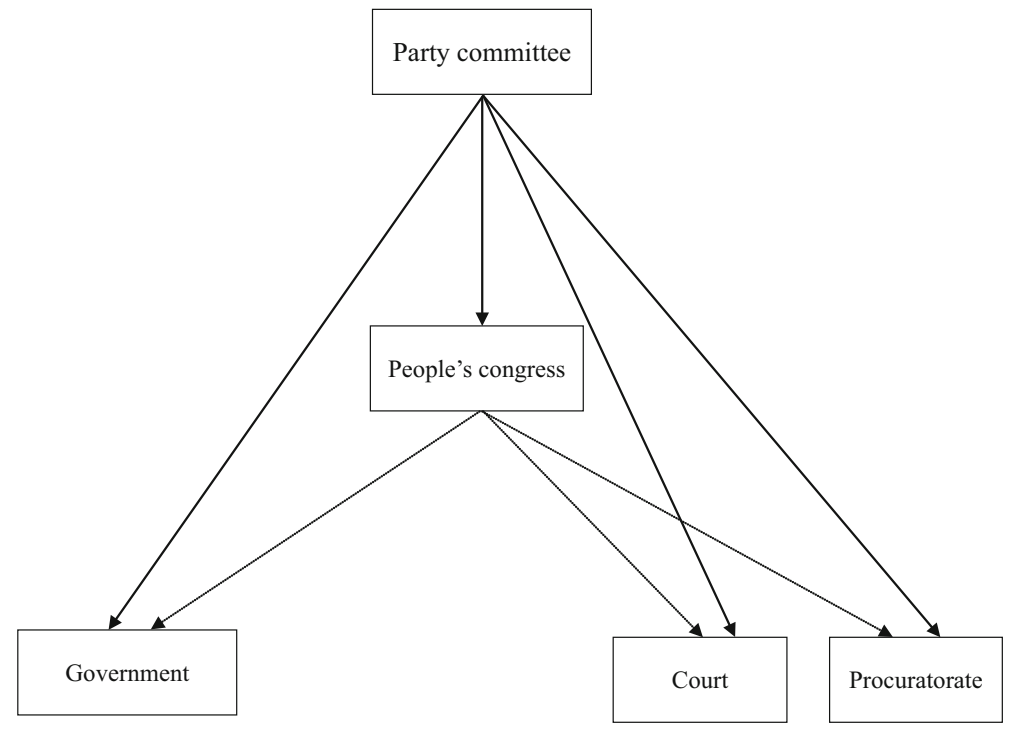

Fig. 1 State Power's Internal Leadership System and Party's Leadership System to State Power. This diagram is designed by the writer. The solid lines demonstrate the Party committee's practical and strong leadership over the people's congress, government, court, and procuratorate through the Party group system, Party committee for organs, the Party group's request for instructions and reporting to the Party committee, systems for approval of the Party's internal cases, and so on. The dashed lines show the statutory leadership of the people's congress over the government, court and procuratorate according to the constitution

departments have much intercross and repetition. Thus, the government's leaders and functional departments are subordinate to the Party committee's leaders and its corresponding departments. It is difficult to separate Party work and government work. Therefore, substitute the Party for the government has thus developed.

Figure 1 can be used to demonstrate the state power's internal leadership system and Party's leadership system to the state power.

\subsection{The System of the Party and State Leadership and Management to Society: Domination and Subordination}

After the completion of socialist transformation of private ownership of the means of production, private economic sectors ceased to exist; civil organizations decreased in number due to the lack of independent financial sources and other reasons; and the public sector became the only one in economic and social life. After the establishment of the planned economy system, since the power of distribution of personnel, resources and opportunities were seized by the Party and government organizations at all levels and their leaders, the scope of plans and instructions gradually expanded from economic life to social life. The Party achieved its leadership over society through the Party committees' leadership over the party leading groups of people's groups and mass organizations, state-owned 
enterprises and institutions, and neighborhood committees, as well as the Party committees of people's communes. Meanwhile, in accordance with the provisions of the 1956 Party Constitution, the Party's grass-roots organizations in enterprises, rural areas, schools and other state-owned or collective enterprises and public institutions "should lead and supervise the administrative agencies and mass organizations actively implement the resolutions of higher Party organizations and higher state organs, and constantly improve the work of their own". In this way, the Party's grass-roots organizations became the core of leadership. The chief executives worked under the leadership of the Party organization, namely, the chief executive responsibility system under the leadership of Party committees was adopted. Both the Party and government leaders of enterprises and institutions and the leaders of Party and government organs were national cadres subject to unified cadre management and deployment rather than classified and used based on different occupations. The Party and state also exerted leadership and management toward society in the following ways: establishing an work unit system in cities with urban workers incorporated into various work units, through which economic and social benefits were provided for individuals and a full range of control of individual thought, work and life was conducted; establishing the street and neighborhood committee system in cities in which non-institutional urban residents were incorporated into management; establishing the people's commune system integrating government administration and community management in rural areas, the farmers were incorporated into group systems like people's communes, production teams and production groups to management; establishing the urbanrural separation household registration system, ticket supply system and the personal files system to impose restrictions on the residents' free movement and migration between urban areas and rural areas; in particular, restricted rural residents now turning into urban residents to enjoy the benefits of the latter and their freedom to change into workers and national cadres. The foregoing Party and state's leadership of society and the management system arising from the overall control of personnel, resources and opportunities have resulted in multiple domination and subordination relationships: Party and government organs dominated state-owned enterprises, institutions, people's groups and mass organizations; Party and government organs were in the dominant position by holding the power of distribution of personnel and resources, in turn, state-owned enterprises, institutions, people's groups and mass organizations were in the subordinate and dependent position; as for the relationship between the leaders of Party and government organs and those of state-owned enterprises, institutions, people's groups and mass organizations, the former have the dominant position by freely deploying the leaders of state-owned enterprises, institutions, people's groups and mass organizations, while the latter who are national cadres have to obey unified deployment; as for the relationship between the leaders and workers in the work unit system, the leaders have the dominant position by holding various economic and social resources as well as promotion opportunities that the workers need, while the workers have to obey leaders. In general, the Party and the government fully control and dominate society, while enterprises, institutions, people's groups and mass organizations which are also public sectors lack the necessary independence and autonomy and 


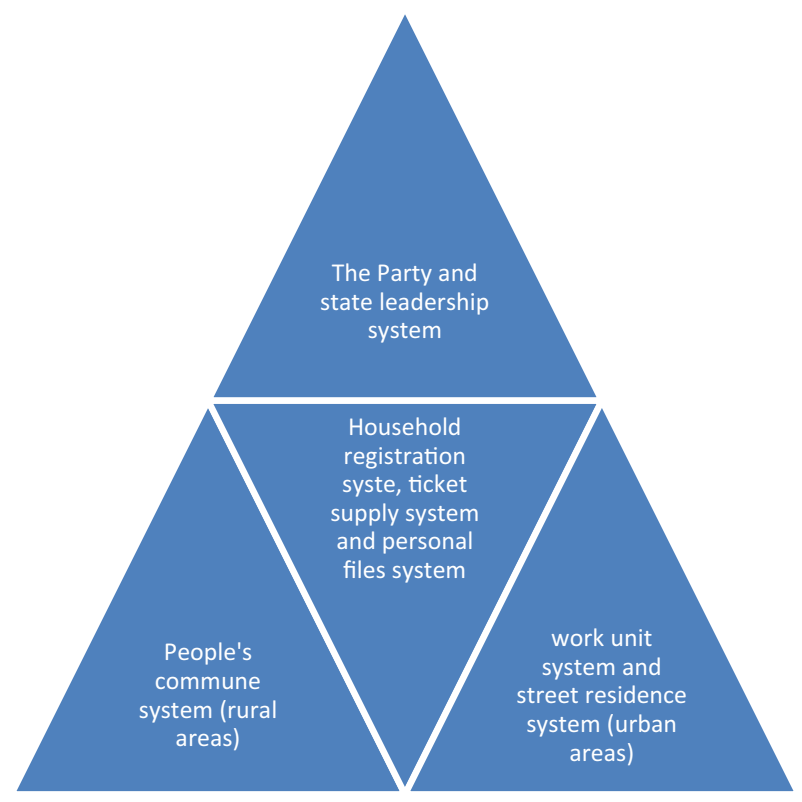

Fig. 2 The Party and state's leadership and management system toward society. This diagram is designed by the writer. The Party and state manage the urban and rural residents by incorporating them into certain organizational systems like work unit system, street residence system, and people's commune system and separating the urban and rural residents through the urban-rural separated household registration system, ticket supply system and personal files system to ensure that they can enjoy different social welfare and benefits respectively. The Party's leadership toward society also extends to the grassroots social community by widely establishing the Party's grass-roots organizations in rural areas and state-owned enterprises, implementing the chief executive responsibility system under the leadership of Party committees, and adopting the responsibility system for external Party committees

individuals don't have the basic freedom to choose residence, occupation and workplace.

Figure 2 can be used to demonstrate the Party and state's leadership system toward society.

\section{The Party's Leadership System: An Inverted Leadership}

In accordance with the provisions of the 1956 Party Constitution, the Chinese Communist Party's organizational principle is democratic centralism. According to this principle, Party organizations have to strictly adhere to the principle of collective leadership and individual responsibility. All party members and organizations must accept the Party's top-down and bottom-up supervision. In accordance with the provisions of the 1956 Party Constitution, the Party's leading bodies at all levels shall be generated by election. The Party congress is the supreme leading agency of the same level of party organizations. When the Congress is in recess, the elected Party committee is the supreme leading agency. The term of 
National Party Congress is 5 years and the annual meeting system is adopted. When the National Party Congress is in recess, the CPC Central Committee leads the entire work of the Party. The Party's Central Committee is organized by the Political Bureau of the Central Committee at least twice a year. The plenary meeting of the CPC Central Committee elects the Politburo, its standing committee and the secretariat of the Central Committee, as well as the Chairman of the Central Committee, a number of vice chairmen, and the General Secretary. When the plenary meeting of the CPC Central Committee is in recess, the Politburo and its standing committee exercise the powers of the Central Committee. It was stated in the Decision of the Central Committee on Adjustment and Streamlining the Central Bodies in 1943 that the Politburo had the right to decide all major issues between two sessions of the plenary meeting of the CPC Central Committee. Mao Zedong was named as the chairman of the Politburo and the secretary of the Secretariat. The chairman had the power to finally decide the issues discussed at the meeting of the Secretariat. The 1956 Party Constitution adopted by the eighth National Congress kept the chairman system and the power of final decision in the chairman system was also inherited as an unwritten rule and habit and as a matter of fact, Chairman Mao Zedong enjoyed this power all the time (Chunxi 2008). After the founding of the People's Republic of China, Comrade Mao Zedong emphasized that important work shall be "under the command of the secretaries", therefore, the secretaries of the Party's local organizations and grass-roots organizations, especially the first secretaries, were actually the supreme leaders. Meanwhile, according to the Party Constitution, the Party Congress is held only once a year; the Central Committee only holds meetings twice a year and the number of the plenary meetings of local Party committees held annually is also limited; therefore, at the local level, the standing committee of Party committee and the secretary's work meeting are in fact the supreme leading agencies; at the central level, the Politburo, especially its standing committee, is in fact the supreme leading agency. The leadership principle of collective leadership and individual responsibility in the standing committee make it convenient for the secretaries to enjoy concentrated power. The leadership principle of collective leadership and individual responsibility that the standing committee adopts is in fact a combination of collegial system and chief executive responsibility system. As the "monitor" of the standing committee, the secretary (the chairman at the central level) has primary responsibility for all work and the right to adjust the specific work of standing committee members and preside over the meetings. Thus, he is not equal with other standing committee members. He has the actual right of decision-making or final decision. Also, in accordance with the provisions of the 1956 Party Constitution, the Party's supervisory committees at each level are elected and controlled by the Party committee at the same level which makes it difficult for the Party's supervisory authority to effectively supervise the Party committee at the same level. Therefore, looking at the relationship on the horizontal basis, the supreme leadership of Party organizations at each level actually lies in the hands of the main leaders of the organization, which is a practical personal leadership system: the chairman (at the central level) and the first secretary (at the local level).

Figure 3 can be used to show the Party's leadership system. 
In accordance with the provisions of the 1956 Party Constitution, there are three levels of party organizations, i.e. central organizations, local organizations and grass-roots organizations. It was stated in the 1956 Party Constitution that the power of central organizations and that of local organizations should be appropriately separated. But more articles therein were adopted to safeguard the Party's centralized leadership and the discipline of subordinates' compliance with the superiors, and the whole Party's compliance with the Central Committee. The Party Constitution clearly provided the leadership of the Party's higher organizations over lower organizations and stressed the need for lower organizations to report work to higher organizations. The Party's higher organizations achieved leadership of lower organizations by means of appointment and management of the leaders of lower party organizations, review and approval of request for instructions and reports from

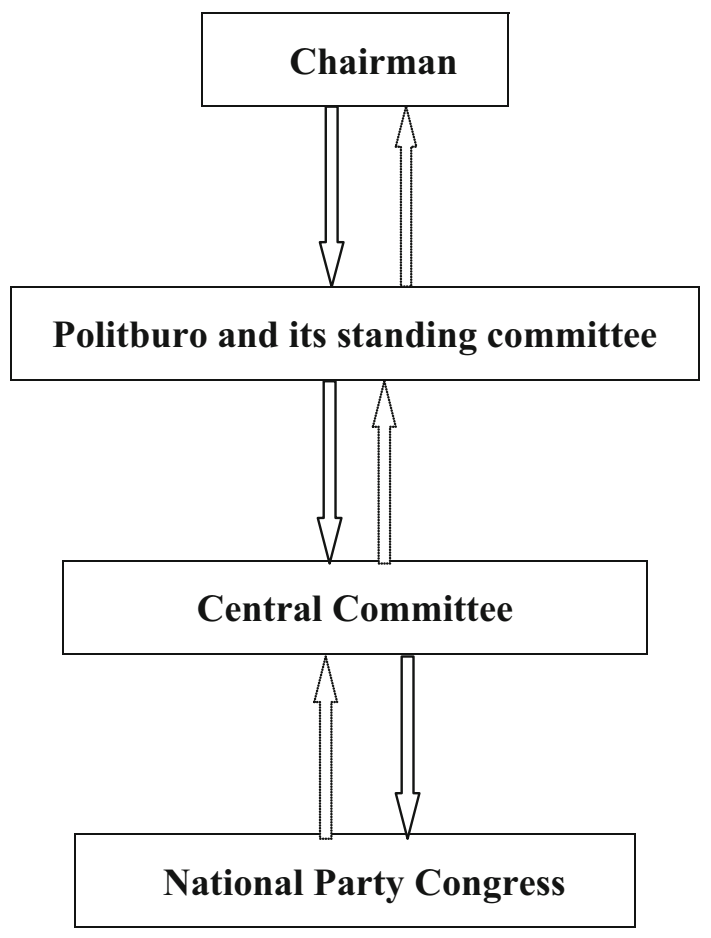

Fig. 3 The Party's leadership system at the central level. This diagram is designed by the writer. In accordance with the provisions of the Party Constitution, the National Party Congress is the Party's supreme leading agency. The Central Committee and local Party committees at all levels are elected by and are accountable to the National People's Congress. The Central Committee elects the Politburo, its standing committee, and the Chairman of the Central Committee. The Politburo acts on behalf of the CPC Central Committee between two sessions of the plenary meeting of the CPC Central Committee. In this way, the direction of leadership is clear. However, as for actual operation, the National Congress is held every 5 years, and the Central Committee meetings are held twice a year at most. The chairman of the Central Committee leads the Central Committee through the Politburo and its standing committee during the recess, thereby leading the whole party in the name of the Party's Central Committee. This inverted relationship also exists in local and grass-roots Party organizations 


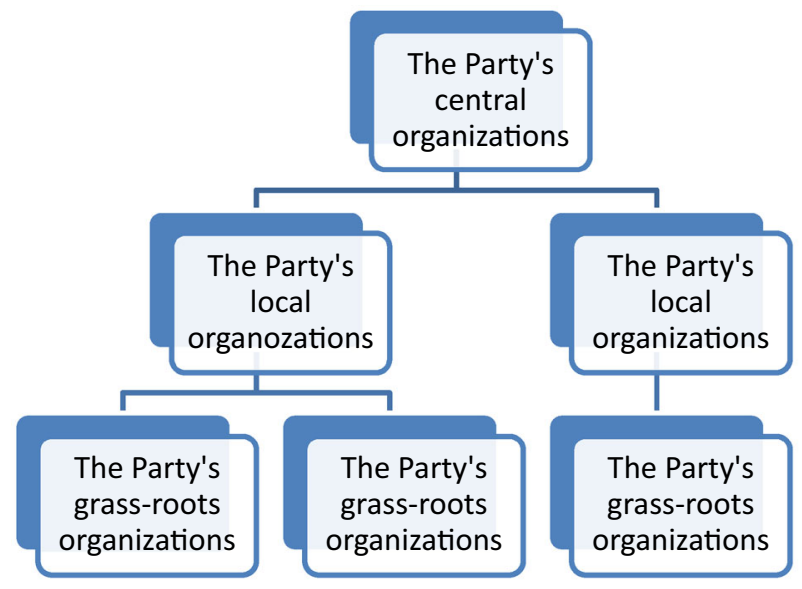

Fig. 4 Relationships between the Party's organizations at all levels. This diagram is designed by the writer. According to the four obedience principles, the Party's grass-roots organizations obey the leadership of local organizations, while the local organizations obey the leadership of central organizations, forming a strict hierarchical organizational structure

lower organizations, and disciplinary supervision. These institutional mechanisms promoted powers' centralization toward higher organizations, especially to the Central Committee (Fig. 4).

The Communist Party of China has also achieved its comprehensive control of state power organizations, economic, social, and cultural organizations by means of widespread establishment of Party leading groups and Party committee systems in power organizations, setup of the Party's grass-roots organizations in economic, social, and cultural organizations, and implementation of chief executive responsibility system under the leadership of Party committees, thereby establishing the Party's highly centralized leadership system. In the traditional Party's centralized leadership system, the relationship among the Party, state and society is an inverted pyramid structure, in which the Party is strong, the state is weak, and the society is small (Fig. 5).

\section{The Basic Pillars of the Traditional Party and State Leadership System}

There are six basic pillars of the traditional Party and state leadership system established after the mid-1950s.

First, state power was used to complete the socialist transformation of private ownership of the means of production (including nationalization and collectivization). All economic, social, and cultural organizations were changed into public sectors based on public ownership. The state power distributed all resources through mandatory plans in a unified manner under the leadership of the Communist Party of China. All economic, social, and cultural organizations became executive agencies 


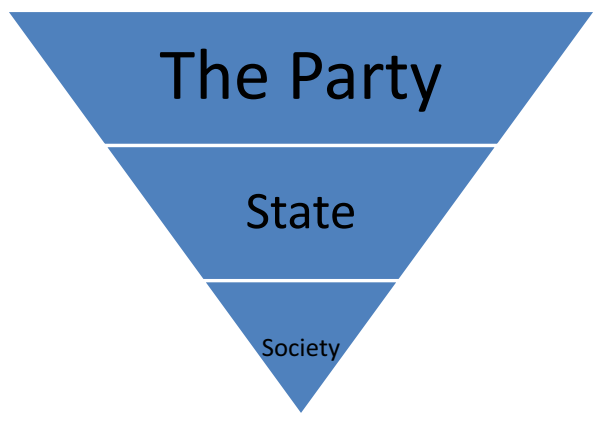

Fig. 5 The relationship among the Party, state and society under the Party's centralized leadership system. This diagram is designed by the writer. The Party achieves the core leadership status by widely establishing Party organizations in the country and society, exerting leadership over these organizations, and establishing systems for the cadres under the leadership of the Party. The state power, particularly the administrative organs, is placed under strict control of Party organizations. The Party and state exercise a comprehensive and strict control of the entire community by incorporating social members into a variety of organizations, widely establishing Party organizations in these organizations, ensuring the core status of the leaders of Party organizations, and creating other supporting systems

of state organs' mandatory plans, and thus, lost their independence and autonomy. Public ownership and planned economy became the basic economic pillar of the traditional Party and state leadership system.

Second, the cadre personnel system whereby the Party manages all cadres was established. Cadres at all levels of the Party organizations and non-Party organizations, including Party and government agencies, state-owned enterprises, and state institutions, are all appointed and removed by the Party committees at all levels and their functional departments. The system that the Party manages cadres goes beyond the boundary between Party organizations and non-Party organizations and ignores the different features of political organizations like Party and government organs, state-owned enterprises, state institutions, economic organizations, social organizations, and cultural organizations, as well as the difference in the work of leadership positions, management positions, professional positions, and technical positions. The cadre personnel system that the Party manages all cadres became an important pillar of the traditional Party and state leadership system.

Third, the system for Party committees at all levels to lead the party organizations in non-Party organizations was established to achieve the Party's leadership. After the establishment of the People's Republic of China, the Communist Party of China established Party organizations in state authorities, state-owned enterprises, state institutions, collective economic organizations, and other non-Party organizations universally, achieving full coverage of Party organizations. Meanwhile, the core leadership status of the Party organizations in the non-Party organizations and the administrative leaders working responsibly under the leadership of Party organizations were clearly stated in the Party Constitution. It also further stated that the Party organizations in non-Party organizations should operate under the leadership of external Party committees at all 


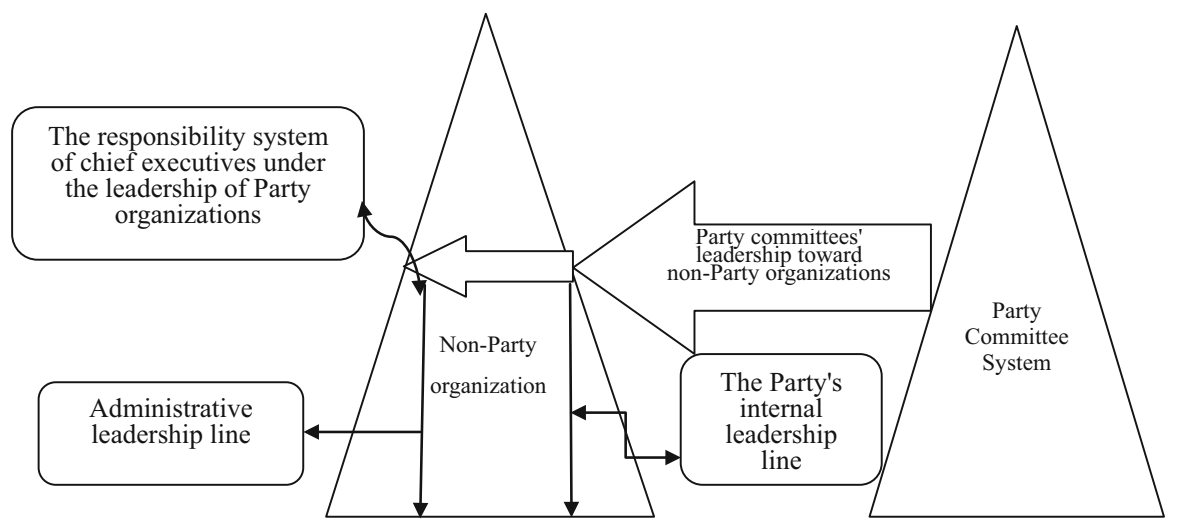

Fig. 6 The Party organizations' organizational leadership over non-Party organizations

levels. ${ }^{3}$ The full coverage of Party organizations and the organizational control mechanism provide organizational guarantee for the traditional Party and state leadership system. Figure 6 can be used to demonstrate the organizational control mechanism.

Fourth, widely establishing work unit systems and using institutional welfare to guarantee the comprehensive obedience to organizations. After the completion of socialist transformation of private ownership of the means of production, all members of society were incorporated into various organizations of the public sector without exception and thus, systematization was fully achieved. As members of organizations (commune members in rural areas), individuals got welfare regarding employment, housing, children's schooling, medical care, pensions and so on through organizations. In turn, individuals were fully dependent on organizations. This work unit system in which institutional welfare is used in exchange for the individuals' absolute obedience to the organization constitutes an important pillar of the traditional Party and state leadership system.

Fifth, identity management was implemented. The identity division between common people and class enemies (landlords, rich peasants, counter-revolutionaries, bad elements, and rightists who were collectively called "Five Black Categories"), between Party members and non-Party members, and between cadres and the masses, was directly linked to the channels and opportunities for social mobility. The Party and government organs at all levels, state-owned enterprises and institutions, collective economic organizations and their leaders judged social classes, developed Party members, appointed and removed cadres based on people's political attitudes and political performance (whether they are politically loyal, reliable, and consciously compliant with leadership), thereby monopolizing the opportunities and channels for upward social mobility. The opportunities and channels for upward mobility including change from agricultural population to non-agricultural population, admission to

\footnotetext{
${ }^{3}$ Hungarian scholar Maria Csanadi was undoubtedly the first to make wonderful analysis of dual leadership connection between traditional socialist parties and state system. Please refer to her book: Csanadi (2008).
} 


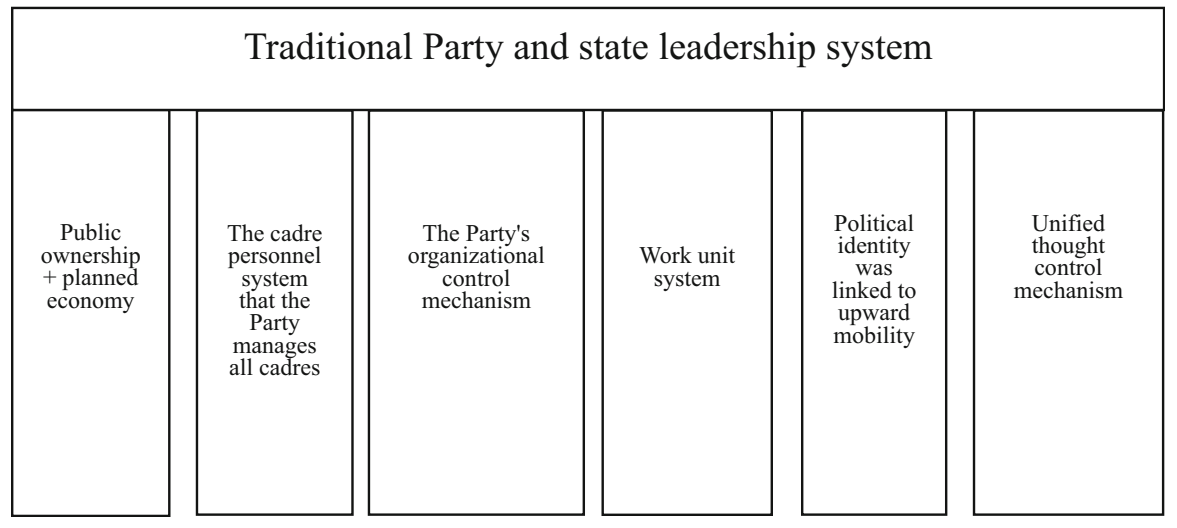

Fig. 7 The six basic pillars of the traditional Party and state leadership system. This diagram is designed by the writer. It briefly shows the six basic pillars of the traditional Party and state leadership system

universities, employment, joining the army, and promotion were directly related to the identity of the group that individuals belonged to. Identity management strengthened the Party's political control of society. The identity management system by which political identity was linked to opportunities for upward mobility became an important pillar of the traditional Party and state leadership system.

Sixth, the thoughts of the Party leader were the only ideology that the whole Party and all people must widely believe in. National cultural and educational agencies, news and publishing agencies, and other organizations were used to instill such binary opposition beliefs in all Party members and people as: Chinese Marxism, i.e. Mao Zedong Thought, is scientific while non-Marxist ideology is unscientific; working-classes represented the Party's advanced features while nonproletarian parties were backward and reactionary; the socialist system was superior while the capitalist system was corrupt. The unique leading position of the thoughts of the Party leader was firmly established to achieve highly ideological consistency of the whole society. The scientific thoughts of the Party leader decided the advancement of the working-class parties and the superiority of the socialist system. The centralized leadership of the thoughts of Party leader provides the traditional Party and state leadership system with an ideologically legal pillar. ${ }^{4}$

Figure 7 can be used to demonstrate the six pillars of the traditional Party and state leadership system.

\section{The Advantages of the Traditional Party and State Leadership System}

The highly centralized traditional Party and state leadership system established after the mid-1950s had its own unique advantages and played an important role in the subsequent socialist modernization.

\footnotetext{
${ }^{4}$ For the ideological pillars of classic socialist system, please refer to: Kornai (2008).
} 
Firstly, with stern disciplines and highly centralized power, the Party organization system achieves and maintains the country's unity and solidarity. With stern disciplines, highly centralized power, and unified organizational systems, the Communist Party of China survived in fierce competition among many political parties in modern China. Not only did it lead the Chinese people to wage the new democratic revolution against imperialism and feudalism, but it also created a strong and centralized modern nation. In the course of socialist transformation of private ownership of the means of production and socialist construction, the Communist Party of China's organizational network achieved full coverage of state power and all types of non-Party organizations. The Chinese Communist Party also established its core leadership position in these organizations. The Party's centralized leadership over the state and society and its huge organizational network extending in all directions played an important role in maintaining the solidarity and unity of the modern nation and ensuring the implementation of decrees.

Secondly, the strong capacity of mobilizing resources and the advantage of doing great things with centralized strengths helped to implement catch-up development strategies. In the process of leading the Chinese revolution, the Chinese Communist Party developed work habits of mobilizing the masses and completing most important works by gathering major strengths, so therefore had powerful advantages of mobilizing the masses and mustering resources. After the founding of the People's Republic of China, the establishment of a highly centralized planned economy, combined with the work style that mobilizing the masses to engage in construction work on a large scale enabled Party and government organizations at all levels to have the strong capacity of mobilizing strong human resources and material resources and the advantage to do great things with centralized strengths. In the process of implementing the catch-up development strategies to catch up the United States and Britain, particularly in the process of "Great Leap Forward", the capacity of mobilizing resources and the advantage to do great things with centralized strengths were exploited to the extreme.

Thirdly, the super political and social control capabilities ensure long-term social and political stability, which is conducive to the smooth progress of modernization. In the traditional Party and state leadership system, due to the Party's strong control of state power and the Party and state's overall control of society, the Party monopolizes all the resources and opportunities and holds the all-encompassing right to distribute interests. Thus, non-Party organizations are dependent on Party organizations; individuals are dependent on the organizations; the subordinates are dependent on the superiors; and local powers are dependent on central power. This kind of domination-subordination relationship established on the basis of distribution of benefits and dependence on resources enables the Party and government organizations at all levels and their leaders to have strong political and social control powers, and thereby maintaining long-term social and political stability. The latter is to some extent conducive to the smooth progress of modernization.

Finally, the ruling party and state power have relatively strong autonomy. The Party's leaders can independently develop, implement and adjust domestic and foreign policies. The traditional Party and state leadership system has formed a political pattern with strong Party, weak state, and small society. In such a political 
pattern, the ruling party, especially its leaders, confronts very small challenges from state and society, and it cannot be swayed by various social and political forces in the country. Besides, it enjoys high autonomy in terms of formulation, implementation and adjustment of policies, which helps China select a path of modernization in line with the national conditions and adjust development strategies in a timely manner according to its own needs.

\section{The Disadvantages of the Traditional Party and State Leadership System}

The highly centralized traditional Party and state leadership system inevitably has its inherent flaws and defects. Comrade Deng Xiaoping said: "As far as the leadership and cadre systems of our Party and state are concerned, the major problems are bureaucracy, over-concentration of power, patriarchal methods, life tenure in leading posts and privileges of various kinds" (Xiaoping 1994). Comrade Deng Xiaoping's analysis was incisive. On this basis, the flaws and shortcomings of the traditional Party and state leadership system can be summed up as follows:

1. The Party management principle which is not based on the legal system and is not bound by the law is above the statutory operation principle of the state, society, and other non-Party organizations; therefore, bureaucracy thrived.

The Communist Party of China came to power based on the political legitimacy of "serving the people wholeheartedly", while the legal legitimacy based on the constitution and laws was not paid sufficient attention for a long time. The aforementioned various systems for the Party's leadership over the state and society did not ascend to the specific provisions of the constitution and laws. And the relationship between the Party's documents and the leaders' instructions and the laws and regulations is not clarified. There are not clear regulations on the legal responsibility derived from the Party's leadership. Actually, there are dual leaderships in various non-Party organizations, i.e. the leadership of Party organizations therein and the legal leadership within organizations. In accordance with the provisions of the Party, the latter should accept the leadership of the former and the Party organizations in these non-Party organizations have to accept the leadership of external Party committees at all levels. Therefore, as for the horizontal relationship between various organizations, the legal executive leadership in nonParty organizations is virtual, while the leadership of Party leading groups or Party committees is practical and the leadership of external Party committees over the internal Party leading groups or Party committees in non-Party organizations is strong. The power of non-Party organizations is transferred from the legal executive or business leaders to the leaders of internal Party leading groups or Party committees, and therefore the executives or business leaders have no power to be responsible for decision-making of the administrative or business work. The system that the Party leading groups or Party committees in non-Party organizations are accountable to and report work to external Party committees results in the further 
transfer of power of non-Party organizations to external Party committees. The nonParty organizations and their internal Party leading groups or Party committees have no power to be responsible for the matters in the range of their own business. Thus, the horizontal pattern that the Party committees have highly centralized power in various organizations at the same level formed. In the longitudinal relationships among central power, local power and grass-roots organizations, the central government, local governments at all levels as well as grass-roots organizations form a legal leadership in accordance with their statutory duty and power. Meanwhile, the Party's central organization, local organizations and grass-roots organizations form a top-down command and execution relationship. And the rigid discipline that "the subordinates obey their superiors and the Party obeys the Central Committee" further strengthens the leader-subordinate relationship within the Party. The statutory leadership gives up to the Party's internal leadersubordinate relationship. Thus, the longitudinal pattern that the Party holds highly centralized power formed.

The Party management principle not only results in the virtual role of the statutory leadership and legal system, but also leads to the neglect of the standardization of leader-subordinate relationship, as well as the administrative and legal construction for responsibility, authority and accountability mechanisms. The Party management principle which is not based on the legal system and is not bound by laws results in that the Party committees hold highly centralized power horizontally and the Central Committee holds highly centralized power vertically. Moreover, "Our Party and government institutions as well as the leadership organizations of various enterprises and institutions did not have strict top-down administrative regulations and personal responsibility for a long time. There were not strict and clear rules for the responsibility and authority of each organ and each person. Therefore, there were not regulations to comply with regardless of the importance of the matters" (Xiaoping 1994). Bureaucracy has therefore thrived. Comrade Deng Xiaoping once profoundly pointed out that, due to the highly centralized power management system and the lagged administrative and legal construction, "Our leading organs at all levels have taken charge of many matters which they should not and cannot handle, or cannot handle efficiently. These matters could have been easily handled by the enterprises, institutions and communities at the grass-roots level, as long as we have proper rules and regulations and they act according to the principles of democratic centralism. Therefore, difficulties have arisen from the custom of referring all these things to the leading organs and central departments of the Party and government. No one is so versatile that he can take on very complex and unfamiliar jobs. This can be said to be one of the main causes of the bureaucracy peculiar to us today... Most people are often unable to handle independently and responsibly matters, big or small, which they should handle, as a result, they could only keep busy all day long making reports to higher levels, seeking instructions from them, writing comments on documents and passing them around" (Xiaoping 1994, p. 328). "Over-concentration of power in the hands of individuals or of a few people means that most functionaries have no decision-making power at all, while the few who do are overburdened. This would inevitably lead to bureaucracy" (Xiaoping 1994). The main manifestations of 
bureaucracy are as follows: the leaders in charge of decision-making stand high above the masses, divorce themselves from the masses and reality, abuse of power, and make decisions blindly and the personnel handling the matters are dilatory, inefficient and irresponsible and they always consult and report regardless of the importance of the matter.

2. The operating mechanism of the standing committee of the Party committee that legislative power and executive power are unified results in the concentration of all powers like decision-making, execution and supervision in the hands of the standing committee of the Party committee, particularly the secretaries. The dictatorship of the secretary would easily lead to patriarchy, decision-making by one person, placing individuals above the organization, and impossibility to correct major policy mistakes in a timely manner.

Comrade Deng Xiaoping said: "Over-concentration of power means inappropriate and indiscriminate concentration of all powers in Party committees in the name of strengthening centralized Party leadership. Moreover, the power of the Party committees is often in the hands of secretaries, especially the first secretaries, who direct and decide everything. Thus, centralized Party leadership often turns into leadership by individuals" (Xiaoping 1994, p. 329). Within the state regime, the statutory leadership of the people's congress over the government, court, and procuratorate and the authority division and restriction relationship between the government, procuratorate and court give up to the Party committee's centralized leadership and coordination of state power. The standing committee of the Party committee holds both the power of making decisions on major issues and the power of specific arrangements for work that should be in the range of executive authority of the government. Meanwhile, the people's congress and the people's political consultative conference which have the responsibility of supervising the work of the government are placed under its leadership. Within the Party, the Party's supervisory organ is placed under the leadership of the Party committee at the same level. Therefore, the supervision of the internal Party exists only in name for the secretary of Party committee. The secretary assumes arbitrary power and his personal power isn't subject to any supervision or restriction, which would easily lead to "a growth of such patriarchal ways as letting only one person have the say and make important decisions, practicing the cult of personality and placing individuals above the organization" (Xiaoping 1994, p. 330). It is also difficult to correct major policy mistakes in a legal and timely manner. The secretary's dictatorship would easily cause people's dependence on the secretary. Due to this kind of personal dependence, the Party's internal democracy and socialist democracy are impossible.

3. The Party's strong control of state power and the Party and state's overall control of society result in the bureaucratic Party organizations and special cadre groups, who standing high above the masses and divorce from the masses, and all kinds of privileges. 
Due to the principle that cadres are placed under the leadership of the Party, the Party's leading bodies and leaders have the power of personnel appointment and removal. And as a result of the systems of special leadership on different sectors and centralized management, the leaders of Party committees at all levels and the functional departments of Party committees further have the power of managing the specific business of government departments. Ruling by the Party and replacing the government with the Party make the Party to be the most important part of the country. Having specific administrative power, the Party's agencies become administrative and bureaucratic. In the trilateral relationships among people, the Party and government, the fact that the Party becomes administrative and bureaucratic has changed its focus of representing and serving the people to the specific daily administrative work and the Party's original functions of developing policies to control the government and serving the people on behalf of the people shrink day by day. The Party and state take a dominant position by monopolizing and allocating all valuable resources by means of planning, while the enterprises, institutions, social organizations and other social forces take a dependent position and serve as subsidiaries of the Party and government. Due to the lack of supervision and control by relatively independent social forces and the lack of constraint of legal power, the Party and government leaders and cadres, who are placed in a top-down cadre appointment system and life-long tenure system and who have interest distribution rights, gradually stand high above the masses, divorce themselves from the masses, and own all kinds of privileges, thus becoming a special group. Deng Xiaoping said: “There are still some cadres who, regarding themselves as masters rather than servants of the people, use their positions to seek personal privileges... The privileges we oppose today are political and economic prerogatives not approved by law or the existing regulations" (Xiaoping 1994). The privileges and specialization of cadres are characterized by the fact that they are politically superior to others and pursue power beyond the law and the fact that they are superior to others in terms of living conditions and enjoy special treatment that ordinary people can't have access to. The cadres have gradually changed from a full-time management personnel group representing and serving the people into a special group representing their own interests, serving themselves, and enjoying various privileges.

4. The fact that the Party organizations fully infiltrate into and control the state, society, and other non-Party organizations lead to "political dominance", high politicization of the whole society, shrinking of professionalism and expertise and the lack of social creativity. And as a result, political turmoil would lead to economic and social instability.

Party organization is actually a political organization. The fact that a party fully infiltrates into and controls the state, society, and other non-Party organizations would inevitably lead to the entire society focusing on politics. Since the Party organizations take a leadership position in state power, enterprises, institutions, and other non-Party organizations, the executive leaders or business leaders work under the leadership of Party leading groups or Party committees and the Party leading 
groups or Party committees in the non-Party organizations need to accept the leadership of external Party committees. The operation principle of political organizations, economic organizations, social organizations, and cultural organizations gives up to the political principle of Party committees, and therefore these organizations become political. The political standards (officially known as "red") for political loyalty and political obedience to the Party go beyond the professionalism, expertise and other professional standards (officially known as "professional") that these organizations need for their operations according to their nature. The Party's political leadership is higher than the administrative leadership, business leadership and other professional leadership that these organizations need. As a result, these organizations and their staff pay much attention to political standards but ignore professional standards and attach more attention to political leadership than to professional leadership and the professionalism and expertise of various non-Party organizations shrink day by day. In the social structure that politics monopolize all resources and opportunities, the society's dependence on the Party and state, the state's dependence on the Party, the subordinates' dependence on the superiors, and the individuals' dependence on the employer or organization result in that all the secondary subsystems of the whole society lack autonomy, ${ }^{5}$ and thus the whole society lacks creativity and vitality. Under the condition of politics dominating everything, the entire society runs with politics as the center and political needs, political tasks and political mobilization have the overriding priority. When economic development is promoted by political logic, the "Great Leap Forward" situation that all forces and resources are mobilized to rapidly and vigorously complete a particular economic work would appear. After the Great Leap Forward, due to the shortage of resources and the constraint of tight budget, large-scale reorganization would appear, and therefore economic ups and downs would appear too. When political turmoil arising from high-level political struggles within the Party, it would spread into a wider range and lead to economic and social instability.

In the period between the establishment of People's Republic of China in 1949 and the mid-1950s, the traditional Party and state leadership system operated with two sets of logic: one is the logic of construction; the other is the logic of revolution. The former took the dominant position, while the latter gave up to and served the former. ${ }^{6}$ After the founding of the People's Republic of China, the Party and state granted priority to economic construction. And in order to lead economic construction, the Party and state organizations continued to improve; the role of technical experts was more important and the hierarchical obedience and instrumental rationality within the bureaucratic agencies further grew. At the same time, the Party committees and governments at all levels were still accustomed to the ways of construction formed in the revolutionary period: political mobilization and mass movement. In order to consolidate the new regime, the Party committees

\footnotetext{
5 Chen Mingming made an in-depth exploration of the relevant drawbacks in the paper The Reason, Morphology and Limitation of Party State-A Discussion on China's Construction of a Modern Nation.

6 For China's political development logic, please refer to: Yu Keping, The Political Development of the People's Republic of China over 60 Years and Keping et al. (2013).
} 
and governments at all levels followed the revolutionary logic in the process of suppressing counter-revolutionaries: distinguishing between enemies and friends, uniting friends, fighting against enemies, and improving their own forces. After the 20th Congress of the Communist Party of the Soviet Union in 1956, the top leaders of the Chinese Communist Party were increasingly concerned about revisionism. And in the Party's Rectification Movement in 1957, the non-Party intellectuals criticized the corruption of the Party and requested for "ruling in turn", which made some of the Party leaders believe that the Party's leadership was challenged. Therefore, during the Anti-Rightist Struggle, the revolutionary logic played a major role and those intellectuals who had criticized the Party were cracked down as Rightists in opposition to the Party. In this way, the Party's leadership was consolidated. In 1958, after the setback of "Great Leap Forward" and the Lushan Conference, the Party's supreme leader believed that his leadership and authority were challenged by senior colleagues in the Party. In order to maintain his leadership and authority, he put the revolutionary logic in the dominant position over the constructional logic. Guided by the thoughts of "permanent revolution" and "continuous revolution", the Party's supreme leader introduced the practice of class struggle to the Party's top members. The so-called Peng Dehuai anti-Party clique, Liu Shaoqi anti-Party clique, and Lin Biao anti-Party clique were cracked down one by one. The revolutionary logic was vividly reflected in the "Cultural Revolution", and even reached to an extreme degree.

The fact that the revolutionary logic prevailed over the constructional logic and took the dominant position in the period of socialist construction might be attributed to the strong historical inertia of revolutionary logic and its special function of consolidating the Party's leadership and the new regime. More importantly, it was the result of full development of defects of the traditional Party and state leadership system. As Comrade Deng Xiaoping pointed out, the main cause of the traditional Party and state leadership system's trouble was excessive concentration of power, that is, in the name of strengthening Party's leadership, all powers were concentrated in Party committees, especially in the hands of the first secretaries. Through Anti-Rightist Movement and the Lushan Conference, the critical voices both inside and outside of the Party were eliminated. Therefore, all powers were highly concentrated in the hands of the Party's supreme leader Comrade Mao Zedong, while there were no necessary measures to supervise and restrict him. Comrade Mao Zedong concerned deeply about bureaucratic tendencies in the Party and government organs and the cadres' divorce from the masses. However, instead of solving these problems through reform to improve the Party and state leadership system, he attempted turning to "permanent revolution" and "continuous revolution" to mobilize the masses to revolt and denounce cadres, so as to break the existing Party and government agencies and crack down the so-called "capitalist roaders". The conflicts between rebel groups and the royalists caused verbal struggle upgrading to armed struggle. Bloody clashes erupted in many places in the early period of the "Cultural Revolution" and the normal social order was destructed. In this situation, the army had to take over local leadership. The army's "support of the Left" and the military representatives' takeover of the government got the army involved in the internal struggle. Thereafter, revolutionary committees 
had to be established to exercise governmental power and Party committees at all levels were restored. Revolutions could not substitute for dinner, so in the late period of Cultural Revolution, "continuous revolution" was forced to change into "grasp revolution and promote production". Economic construction was once again given attention. The Cultural Revolution started with the Party leader's mobilization of the masses to "smash the public security organs, procuratorial organs, and people's courts", and "kick aside Party committees to make revolution", and ended with the recovery of the Party committees at all levels. The Party leaders tried to use the revolutionary logic to overcome some drawbacks of the traditional Party and sate leadership system. However, "continue the revolution under the dictatorship of the proletariat" destructed the legal system and caused vicious development of rule of man, destructed the social order and caused sectarian clashes and nationwide unrest, as well as destructed the process of modernization and caused economic and social stagnation, rather than overcome any shortcomings of the traditional Party and state leadership system. This shows that the revolutionary logic was unable to solve the drawbacks of the Party and state leadership system under the ruling conditions.

\section{References}

Chunxi, Wang. 2008. Deng Xiaoping's contribution to the establishment of the CPC Central Committee General Secretary System and the Collective Leadership System. CASS Journal of Political Science 21: 6 .

Csanadi, Maria. 2008. Self-consuming evolutions: party—model and evolution of state system. Beijing: Central Compilation and Translation Press.

Keping, Yu., Li Kanru, et al. 2013. China's political development: from the view of American and Chinese scholars, 39-62. Beijing: Social Sciences Academic Press.

Kornai, Janos (Hungary). 2008. The socialist system-the political economics of communism. Trans. Zhang An, 45-56. Beijing: Central Compilation and Translation Press.

Song, Pang, and Han Gang. 1987. History and future of the reform of party and state leadership system. Chinese Social Science 6: 14-15.

Xiaoping, Deng. 1994. On the reform of the Party and state leadership system (August 18, 1980). In Collected works of Deng Xiaoping, vol. II. $2^{\text {nd }}$ ed, 327-332. Beijing: People's Publishing House.

Zedong, Mao. 1986. A speech given at the enlarged central work meeting (January 30, 1962). In selected readings from the works of Mao Tse-Tung (Second Book), 832. Beijing: People's Publishing House (1986).

Zedong, Mao. 1999. The Party's leadership responsibility for government work (December 1952). In Collected Works of Mao Zedong, vol. VI. $1^{\text {st }}$ ed, 252. People's Publishing House, Delhi (1999).

Zengke He is a Professor at Research Center for Chinese Politics in Peking University. Professor He received his Ph.D. in Political Science from Peking University in 1991. He was a visiting scholar at Bradford University and Nottingham University in the UK from 1997 to 1998 and a trainee for Executive Development Courses at Duke University in 2005. He had attended Kennedy School of Government at Harvard University as a visiting scholar from August 2014 to Febrarury 2015. His research interests include corruption and anti-corruption, political reform and government innovation, civil society, and social reform. He is the author of Civil Society and Democratic Governance (Beijing: Central Compilation \& Translation Press, 2007). His latest book is Government's Governance (Beijing: Central Translation and Compilition Press, 2015). 